\title{
Phenomenological Study of Poso Terrorists Ex-Inmates Community: The Identity Transformation: from Terrorists to Caravan Warrior of Peace
}

\author{
Lukman S. Thahir \\ \{lukmanst65@iain.ac.id\} \\ Faculty of Ushuluddin, Adab and dakwah, IAIN Palu, Central Sulawesi, Indonesia
}

\begin{abstract}
This article is the result of the research on the Phenomenological Study of Poso Terrorists Ex-Inmates Community (The Identity Transformation: from Terrorists to Caravan Warrior of Peace) conducted in Poso Regency, Central Sulawesi, Indonesia. The objective of this study was to cut the chain of terrorist movement by changing their mindsets which are based on very complex behaviors and factors to transform their identities from terrorists to peace fighters. The main questions of this research were focused on: 1) How did the terrorist ex-inmates identify themselves before experiencing an identity transformation process). How did the process of identity transformation take place amongst the terrorist ex-inmates and 3) How did the terrorist ex-inmates identify themselves after the transformation? Phenomenological descriptive and psychological analysis of John Morgan's disengagement model were employed to answer these problems. Data collection techniques employed were observation, in-depth interview and documentation. The results show that 1) the terrorist ex-inmates of Poso identified themselves, prior to the transformation of the identity, as mujahidin or jihadists of Poso; 2) the transformation process took place within two phases, psychological and physical, elaborated by employing the 7th habit of effective people; and 3) the terrorist ex-inmates identified themselves, after the transformation, as Caravan Warrior of Peace indicated by their role as a counter-terrorism speakers amongst community members.
\end{abstract}

Keywords: Phenomenology, Terrorism, Terrorist ex-Inmate, Identity Transformation, Caravan Warrior of Peace

\section{Introduction}

Terrorism has long been considered a very precarious and inescapable problem in the world because its impact not only threatens national security, integrity and economy [1], but it also threatens the right to life of all mankind [2]. In the Global Report of Terrorism Index, 2017, it was revealed that the rate of deaths due to terrorism has dramatically increased over the past 15 years. The number of people who have died due to terrorist activities has increased nine-fold since 2000. In 2014, the total number of deaths as a consequence of terrorist activities reached 32,685, an increase of 80 percent from 18,111 the previous year. This is the highest level ever recorded. Most of these deaths, i.e. more than 78 percent, occurred in only five countries: Iraq, Nigeria, Afghanistan, Pakistan and Syria [3]. For details, see Figure 1 below: 


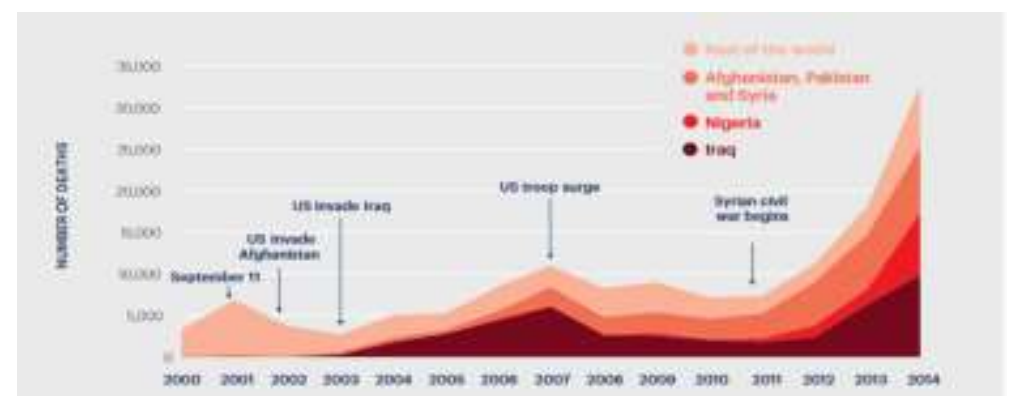

Fig. 1. Death Rate Due to Terrorism in 2014

Although terrorism highly concentrates on a small number of countries, the impact, especially the number of countries that have terrorist attacks has also increased. In 2014, for example, there were more countries affected by terrorism than before. The attacks recorded increase from88 in 2013 to be 93 countries within one year. This trend continues to increase with more countries experiencing terrorist attacks which cause a massive number of deaths every year [3], including Indonesia. With the increasing number of countries affected and the ever-escalating rate of deaths, each year due to terrorist attacks, drums against global terrorism become a stipulation for every country. Indonesia, for example, especially after the Bali bombing, 2002, took three strategic steps to prevent the increase of terrorism. First, on April 4, 2003, the Government of Indonesia ratified Law Number 15, 2003 concerning Eradication of the Criminal Acts of Terrorism. Second, on August 26, 2004, the Government of Indonesia again established the Anti-Terror Special Forces named as "Special Detachment 88".Third, to strengthen the previous strategic steps, on July 16, 2010, the Government of Indonesia established the National Agency for the Prevention of Terrorism.

By the establishment of a "legal umbrella" and the establishment of the two institutions, Indonesia has shown its strong commitment and taken a measured role in combating and preventing terrorism in the world. However, in its development, the act of countering terrorism has left various problems, especially between law enforcement on one hand and prevention on the other. Therefore, it is necessary to rethink its counter-terrorism concepts, approaches, and strategies. Borrowing the analysis of the Institute for Policy Analysis of Conflict, between 2005 and 2009, especially after the police succeeded to dismantle the main terrorist base in Poso in 2007, Indonesia received extraordinary praise from the international world and its success was considered as a form of the word victory in the fight against terrorism". Despite the victory, in the end, it was all in a form of law enforcement but not prevention [4]. The strengthening of the prevention side was emphasized by the establishment of the BNPT, the National Counterterrorism Agency. However, the institution that was initiated by Mr. President, Susilo Bambang Yudhoyono, had not yet been able to formulate a well-established concept of de-radicalization, especially concerning de-radicalization of terrorist prisoners and ex-terrorist inmates. The National Counterterrorism Agency - BNPT program, according to the Asia Report No 142 report to date, has been mostly seen as a separate part of other developments and without much questioning about causes and consequences [5].

To break the deadlock of the concept, the author agrees with Julie Chernov Hwang, Rizal Panggabean, and Ihsan Ali Fauzi [6], in the Disengagement of Jihadists in Poso which states that disengagement is a gradual process of internal reflection that could not recover quickly, but for months and even longer. What is different from Julie Chernov Hwang et al is that the 
author sees the disengagement process does not only breaks violent behavior of ex-terrorist inmates but also at the same time it encourages them to become peace fighters.

This article is the result of the author's research to the ex-Poso terrorist inmate community for a year, which was conducted from August 2018 to 2019. The article aims to break the chain of terrorism among ex-terrorist inmates by changing the mindset of ex-terrorist prisoners based on behavior and complex factors (rational, emotional, psychological and relational) so that their identity transforms from being terrorists to peacekeepers. The main questions are focused on (1) how did these ex-terrorist inmates groups interpret their identity before undergoing a process of identity transformation?, (2)how did the process of identity transformation occur in the ex-terrorist community? and (3) how did the ex-terrorist community interpret themselves at the post-transformation identity?

\section{Research methods}

This study of the community of ex-Poso terrorist inmates is qualitative. Borrowing the opinions of Burns and Grove [7], qualitative research is a systematic and subjective approach to highlighting and explaining everyday life experiences of the research subjects and to better provide them (read: Ex-terrorist communities) meaning for their lives. Thus, this study allows the researcher to deeply explore behaviors, different perspectives, and life experiences of exterrorist inmates of Poso to discover the complexity of the situation through a holistic framework. To explain the meaning and complexity of the life experiences of ex-Poso terrorist inmates, the tool used is phenomenology. It is an approach to qualitative research that focuses on the commonality of a lived experience within a particular group [8]. As an approach that focuses on the similarity of life experiences in a particular group, the phenomenology approach used in this research is descriptive phenomenology [9], an approach that involves direct exploration, analysis, and description of specific phenomena, in this case, ex-Poso terrorist inmates. There is three descriptive steps of phenomenology that have been used in this study: (1) intuition; the researcher fully mingles with ex-prisoners so that he begins to know phenomena concerning ex-terrorist inmates as explained by them. The researcher avoids all their criticisms, appraisals, or opinions and pays tribute to their willingness to be investigated by showing empathy and seriousness towards them. (2) analyze; after the data is obtained, it is then analyzed to be identified, then presented to ex-terrorist inmates. Here, the researcher must be able to distinguish which elements are important and which are not. In this way, it will be seen which are common and which are essential. Therefore, the researcher must dissolve into data obtained when necessary to ensure that the data description is pure and accurate. and (3) presentation; this presentation is to communicate the ex-terrorist inmates' life experiences in the form of written verbal descriptions [9]. Here, the researcher seeks to classify ex-terrorist inmates to avoid premature descriptions.

In addition to the descriptive phenomenology approach, this study was also strengthened by the use of Max Weber's[10]verstehen analysis method, John Morgan's [11] model of psychology analysis, and the authors' own research findings related to mental formation patterns of terrorist prisoners, which theoretically and conceptually, their designs were inspired by the thinking of Covey Leadership Center [12], in order to be more easily understood by the ex-terrorist inmates community. In this context, there are three processes undertaken. First, the process of understanding or verstehen is aimed to understand the meaning that underlies and surrounds social and historical events[13]. Here, the understanding 
is not merely a kind of introspection of motives or subjective meanings but is required to build empathy. The second process is to interpret life through three triadic identity transformation processes: 1. building truth (trust) to ex-terrorist inmates, 2. discussing ex-terrorist inmates human life cycle, and 3, affirming habits or principles of effective human habits from Covey Leadership center,[14] and the third, it is self-actualization or borrowing the term of John Morgan [15], physical process, in the sense of, 'leaving' or simply moving into a different kind of role. Specifically for this change in role, a key factor in transformation, according to Morgan, is by borrowing Garfinkel's note, " is the role played by personal relationships:" change often hinges on a relationship with a mentor or a friend who supports and promotes peaceful behavior ". For details, see Figure 2 below:

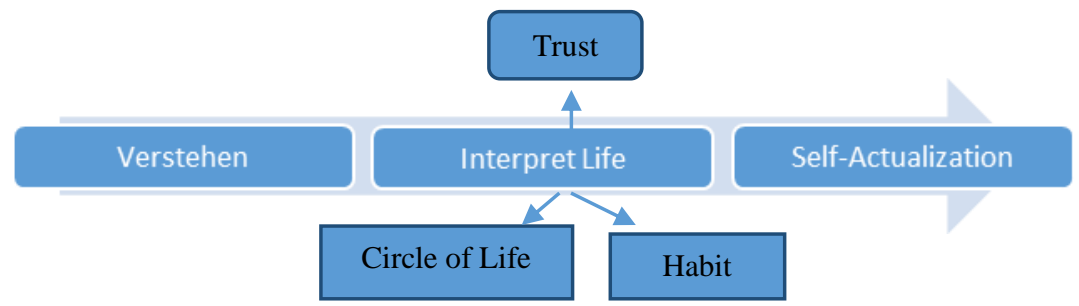

Fig. 2. Identity Transformation Process

Data collection techniques employed in this study are observation, in-depth interviews, and documentation. The selection of informants as many as 5 ex-terrorist inmates was carried out by applying purposive sampling, namely determining to sample by its specific characteristics that were already known. All data obtained is analyzed through the process of data reduction, data presentation, and concluding.

\section{Result and discussion}

To have a more systematic description of the results of the study with specific reference to the focus of the problem, the presentation is classified into three themes: a). The existence of Pre-Identity Transformation of ex-terrorist inmates, b). The Identity Transformation Process of Poso ex-terrorist inmates, and c). The Post-Transformation Identity of ex-terrorist inmates. To describe who and how the five ex-terrorist convicts interpreted or identified themselves before the transformation of identity took place, it helps me to present a brief story of each of them, as elaborated in the following sections: (1) Amril Ngiode. Many people in his village were shocked and distrusted when the Special Detachment 88 announced that this young man was one of the Poso terrorists wanted person lists for the Tentena market bombing, the Emanuel Palu church bomb, and the stealing of gold figures in the old market, Bambaru, Palu. The community at that time, including his parents, held demonstration rejecting the accusation and considered the police to have done a wrongful arrest. They did not believe that the young man who was known to be friendly, quiet, and did not interact much with neighbors and his community in his village, could be so brave to blow up the Tentena market with a bomb. However, after almost a year or so, especially when Amril Ngiode returned to Poso, after hiding in Morowali Regency for 6 months and 3 months in Solo, Central Java, at the urging of his parents, a man born on 7 October 1978 in Bonesompe, Poso, Central Sulawesi 
surrendered to the police, (2) Ardin Djantu. Like Aat, Ardin Djantu, alias Rojak, born in the village of Lawanga Poso, was also included in the Special Detachment 88wanted persons list, as an actor in the Tentena market bombing, shooting at the Priest Susianti, and stealing at a gold shop in the old market of Palu. The difference from the case of Aat, Ardin did not surrender himself to the police. Instead, he fought and kept fighting against the Special Detachment 88 troops, in his area, Lawanga. From this area, after a few days of fighting, he retreated and joined his friends in Kayamanya, an area in the town of Poso which is recorded as one of the jihadist groups' defense areas, besides Tanah Runtuh as the center of movement or resistance) from the Poso Jihadis youth community at that time. In this place, in the battle against the police, although he was shot both in his legs and hands, he was still standing and fighting. However, due to a large number of the Special Detachment 88troops which was assisted by a barracuda car, he then retreated to find a hiding place. Unfortunately, due to his physical weakness, finally, he was caught by the Special Detachment 88 . Based on this case, he was sentenced to for16 years [18].

Furthermore (3) is Yudi Heryanto Parsan. In contrast to Aat and Ardin, Yudi Parsan, alias Udit, was not directly involved in various shootings, killings or bombings that occurred in Poso and Palu. Technically, Yudi was born on July 26, 1977, in Ampana, Poso Regency. He was a surveyor and field coordinator; whose job is to conduct a site survey or arrange all planned acts of violence that will be carried out. For example, how to prepare, survey locations, shootings, and post-shootings, where to go, and how long was the execution carried out, everything. It is this young man, born in Poso and of Javanese origin who coordinates all the plans. He was arrested by the Special Detachment 88, and imprisoned for 10 years and 3 months, in the case of the shooting of Priest Susianti Tinulele at the Elfatha Church in Palu, July 18, 2004, (4) Hasanudin. Amongst the former terrorist convicts at that time, Hasanuddin alias Slamet Raharjo was born on December 29, 1976, considered as the most influential and the leader figure. The man, originally from Wonogiri, Central Java, was a student of the 1998 Moro Military Academy, the Philippines that belong to the Moro Islamic Liberation Front (MILF) group. After graduating from the academy, in February 2000, he was instructed by his instructor, Nasir Abbas to fight on the battlefield with the MILF for two years. In 2002, when he was 25 years old, he returned to Indonesia, brought directly by Nasir Abbas. He left for Poso to take over leadership of Tanah Runtuh Poso, one of the centers for the struggle of the Jama'ah Islamiyah in Indonesia.

It was during the reign of ustadz Hasan, as he was usually called by his fostered children at that time, the upheaval of terrorism found its true form. With their strategic capability and experience when helping the MILF in the Philippines, the State (the Government of Indonesia), in this case, the police institution, is no longer dealing with the terrorist groups alone, but also with people who support and sympathize with their group's fight. Starting from the blasting of the Tentena bombing, the beheading of the village leader of Penedapa Poso, the robbery of a gold shop in Palu, the bombing of the pig market in Maesa Palu, the bombing of the Emanuel Church in Palu, the shooting of Susianti, a priest, to its peak, the mutilation of 7 female students of Poso Christian High School, all under the control of his leadership. He was arrested in Palu, in the last-mentioned case, after the arrest of Haris in Tolitoli, the head of the regional coordinator of Palu, with a 20-year prison sentence.

Finally, (5) Fitrah. In contrast to his fore-mentioned seniors, this young man only appeared later and there was no alias of him. His name became famous, because the criminal case he did was the stealing of a van (a boxcar) with Santoso, on August 3, 2004. The latter figure initially joined the Tanah Runtuh group, but later, especially after his seniors, such as Aat, Ardin, Yudi, and its leader ustadz Hasan were arrested by Special Detachment 88, joined 
the ISIS trans-national ideology, and became the MIT leader in Poso. Santoso's presence in the coastal region of Poso brought new enthusiasm for the young people there, including Fitrah. At that time, he was born on June 28, 1984, in the village of Masamba, Poso Pesisir, was only 20 years old. For more detailed descriptions about the five former terrorist convicts presented above, see Table 3 concerning the Pre-Transformation Ex-terrorist Inmates Identity below:

Table 3. Pre-Transformation Ex-terrorist Inmates Identity

\begin{tabular}{|c|c|c|c|c|c|c|}
\hline No & Name & Alias & $\begin{array}{l}\text { Place and Date } \\
\text { of Birth }\end{array}$ & Criminal Case & $\begin{array}{l}\text { Length of } \\
\text { Sentence }\end{array}$ & Age \\
\hline 1. & $\begin{array}{l}\text { Amril } \\
\text { Ngiode }\end{array}$ & $\begin{array}{c}\text { Aat, } \\
\text { Memet, } \\
\text { Ujang, }\end{array}$ & $\begin{array}{c}\text { Bonesompe, } \\
\text { Poso, Oktober 7, } \\
1978\end{array}$ & $\begin{array}{l}\text { Tentena Traditional } \\
\text { Market Bombing, } \\
\text { Emmanuel Church } \\
\text { Bombing in Palu, and } \\
\text { Stealing at a Gold Shop } \\
\text { in the Old Market, Palu }\end{array}$ & $\begin{array}{c}16 \\
\text { years }\end{array}$ & 24 \\
\hline 2. & Ardin Djantu & Rojak & $\begin{array}{l}\text { Lawanga, Poso, } \\
\text { on Juni } 15,1971\end{array}$ & $\begin{array}{c}\text { Tentena Traditional } \\
\text { Market Bombing, } \\
\text { Shooting Priest Susianti, } \\
\text { and Stealing at a Gold } \\
\text { Shop in the Old Market } \\
\text { Palu }\end{array}$ & $\begin{array}{c}16 \\
\text { years }\end{array}$ & 30 \\
\hline 3. & Yudi Parsan & Udit & $\begin{array}{c}\text { Ampana, Poso } \\
\text { On Juli 26, } 1977\end{array}$ & $\begin{array}{c}\text { Shooting Priest Susianti, } \\
\text { Palu }\end{array}$ & $\begin{array}{c}10 \\
\text { years }\end{array}$ & 24 \\
\hline 4. & Hasanudin & $\begin{array}{l}\text { Hasan, } \\
\text { Slamet } \\
\text { Raharjo }\end{array}$ & $\begin{array}{l}\text { Wonogiri, Jawa } \\
\text { Tengah, } \\
\text { December, } \\
271976\end{array}$ & $\begin{array}{c}\text { Mutilation of } 7 \\
\text { Christian Senior High } \\
\text { School Students }\end{array}$ & $\begin{array}{c}20 \\
\text { years }\end{array}$ & 25 \\
\hline 5. & Fitrah & & $\begin{array}{c}\text { Masamba, } \\
\text { District Poso, } \\
\text { Juni } 281984\end{array}$ & $\begin{array}{l}\text { Stealing Van with } \\
\text { Santoso }\end{array}$ & $\begin{array}{c}3 \\
\text { years }\end{array}$ & 20 \\
\hline
\end{tabular}

That is a brief description of the five ex-terrorist inmates of Poso before they undergo the process of identity transformation. Since they were arrested, detained, and convicted, even after being released from prison, they have consistently interpreted or identified themselves as Poso Mujahidin groups or Poso Jihadists.

The difficulties of handling this problem require a variety of approaches, strategies and special tips so that both ex-convicted terrorists and researchers have no prejudices and distance between each other. For this purpose, there are three strategic steps used to better understand the identity transformation process amongst the ex-terrorist inmates:

First, the understanding or verstehen process, borrowing Max Weber's theory [24], is employed to find an in-depth understanding of the community of ex-terrorist convicts. This process is understood as a method, aiming at gaining a valid understanding of the subjective meanings of the actions of the ex-terrorist inmates. Here, the understanding is not just an introspection that can provide an understanding of their motives or subjective meanings, but is required to empathize, the ability to place oneself in the frame of mind of others whose behavior would be explained in terms of the perspectives of ex-terrorist inmates.

In this way of understanding, a descriptive phenomenology approach is employed where three strategic steps are taken: 1. Intuition. Here, the researcher mingles with them, empathize with their problems so he could understand how they feel, and discuss to find solutions to the 
problems they encounter, through family recreation activities in one of the recreation parks on one of the beaches in Poso. For the atmosphere is out of disturbance, the site is specially ordered to avoid the crowd. Thus, the researcher and the ex-terrorist inmates who are in the location could speak without obstruction. This effort was carried out to prove that the researcher was very empathetic to the ex-terrorist inmates and being able to feel their inner feelings and moods.

The next step is Analyzing. Here, the researcher analyzes all the data obtained at the meeting. Among the many complaints and problems, they faced, these parts are analyzed and identified, and then presented to the ex-terrorist inmates so that what the researcher understand is similar to what they understand. Some of the ex-terrorist inmates' issues that have been analyzed and identified as problems such as strong prejudices from public and government, especially police institutions in regards to suspicion of those who still hold the ideology of jihadists. The ex-terrorist inmates find it difficult to find jobs to provide provisions and economic needs of their families.Consequently, most of them have taken shortcuts to becoming contractors, even though they do not have adequate skills in that field. To answer this challenge, step 3, Describing is presented.

Describing and communicating the experience of the ex-terrorist inmates in the form of written verbal descriptions, the Focus Group Discussion (FGD) was employed. In the FGDs which involves not only themselves as the ex-terrorist prisoners, but also includes the government, the community, and the police, negative prejudices over their identities and other problems that block their minds can be answered in positive or negative ways. The results of the FGDs were beyond the expectations of the ex-terrorist inmates. The society, in general, views them as heroes. If there were people who looked them down, they would be newcomers and would not understand the problem in Poso. That is what Adnan Arsal, the Chair of the Poso Muslim Community Forum once said. In a similar tone with the statement of Adnan Arsal, the Chairman of Muhammadiyah, Abdu, and the Chairman of Poso Alkhairaat Regional Branch, Arifin Tuamaka, both of whom were called ex-terrorist inmates with the Islamic fighters or the jihadists, made mention that the ex-terrorist inmates were the fighters of Islam.

The second stage that must be done is a process for the meaning of their lives. Why do you have to make sense of life? Because mingling and taking the attention of the ex-terrorist inmates cannot be a single guarantee for their self-disclosure. It could take trust, interdependence, and habits that are very effective to dismantle their suspicion and mistrust towards people who are from outside their community, which means the other. Trust is the first and foremost step in the process of change or self-transformation. Here, the action speaks louder than words. Therefore, to get the trust of the ex-terrorist inmates, the solution is to take action as many as possible to solve the problems of their lives. The trust ofHasanudin, for example, one person who was mentioned from this group, had been in my hand not only since he was in prison, but also after he left the prison. Once, in 2015, not long after leaving jail, Hasanudin contacted me intending to ask for help for his wife's intention to sell fried rice. At that time, he needed funds for approximately Rp. 30,000 000 (thirty million IDR), to buy a cart, tent, several chairs, and tables. I wanted to help him, and thereby I contacted several friends of mine, and finally, the problem was resolved.

By this belief, the second strategy is to understand the journey of the human life cycle from dependence, such as infants to their parents, then move independently, work and get married, until interdependence of one another. The latter was discussed more with the five exterrorist inmates, because they, with their terrorist background, could not do much, except through the help of others. For example, when Ardin, Yudi, wanted to get a project from the government of Poso, both of them needed other people for them to address their needs to the 
Regent. And when this was conveyed to the regent of Poso, Darmin Sigilipu, he responded well.

The third or final strategy of the process of interpreting life is a habit. The concept of habit was inspired by Steven Covey [14], whose description was adapted to the understanding of ex-terrorist inmates. Of the 7 effective habits, only two of them are broken down into the interests of changing mindsets of the ex-terrorist community. Thus, they are ready to change their identities, from a jihadist or terrorist to peace fighters, namely the concept of being proactive and re-writing self-script.

Being proactive can be interpreted that as humans, we are responsible for our own lives, or in other words, our behavior is a function of our decisions. In a long and relaxed discussion with the five ex-terrorist inmates, it was described that life, whoever it may be, depends on how they respond to it. There are two forms of human responses to any type of event: reactive and proactive. Reactive people are often influenced by their physical environment. If the weather is good, they become happy, and if not, the weather affects their attitude. Proactive people can set their weather whether it's rainy or sunny makes no difference to them, because it's driven by values. What you did before, you must believe it because there was a value that was fought for, regardless of whether it is wrong or right, and you were already responsible for it. That means you are a proactive person. Amongst their positive actions, they involved themselves in the activities of their societies, following the government programs, and ultimately, they are the subject of change in their area.

For this purpose, in an attempt to strengthen and encourage them to change their roles, writing this manuscript is a must. Two cases that were similar to the lives they had experienced were discussed with the researcher, namely the case of Victor Frankl, who was imprisoned in a Nazi German death camp, he then used divine grace, which was not found in all of God's creatures, except in humans, namely that humans have freedom to make a choice. The second case is the story of Anwar Sadat, the former president of Egypt, which in the original text before he became a president, was written in a hatred manner with Israel. For example, he said on National TV, "I will never shake hands with Israelis as long as they still occupy an inch of Arab land". But it was in this prison that he began to rewrite his script. And when the time came, when he became the president of Egypt, he visited Knesset in Jerusalem and opened one of the most exemplary peace movements in world history, a bold initiative that eventually resulted in the Camp David Accord [14].

These two attitudes, proactive and self-written script, are the main materials for the exterrorist inmate's contemplation. Hasanaudin, for example, who was then followed by other colleagues of him, a few days later asked the researcher to review and give an independent study of this concept. Upon this request, the researcher prepared everything, including renting a larger hotel room in Poso to be used as a meeting place. After a long day of discussion with the five ex-terrorist inmates, they agreed to change their role and make a new self-written script called Peace Warrior Caravan. This manuscript was proposed by Hasanudin who was approved by his colleagues. They also appointed Hasanudin as an amir or leader, arguing that previously in the movement of Posojihadis, Hasanudin was their amir (leader). Thus, now the preparation of this new manuscript, Hasanudinwas inaugurated as a chairman or amir)for the Peace Warrior Caravan.

The third step is self-actualization where two processes are used: Theory and Practice. For theory, the ex-terrorist inmates are given basic knowledge of public relations - how to deal with people who are different from their community, especially when the attitude they show with others in terms of religious understanding, thoughts, and opinions different from what they embrace - and public speaking, how they appear in public and explain their 
experiences properly and correctly. For practice, it was first agreed with them what material content would be delivered, then the researcher prepared the draft, and practiced it as it appeared in front of the crowd. For material content, there are three aspects included in 1. Introduce themselves by calling their case. 2. State the reasons and motives for the violence they underwent. 3. Briefly describe the process of violence they carried out, and 4. Deliver messages of peace. For a better understanding of this case, the process will be explained in the post-Transformation Ex-terrorist Inmates Identity presented below.

As explained previously, the Ex-terrorist community has agreed, interpreted and identified themselves with the Peace Warrior Caravan. This caravan must be accompanied and directed to follow the concept of Garfinkel, a former convict, quoted by John Morgan. The concept, the role played is a personal relationship, where changes towards peaceful behavior depend on their relationship with their mentor, in this case, the researcher himself.

Before they come to the arena, in the sense of peace work, two aspects need to be formulated: first, the object of their activity, and second, what kind of activity content should be agreed upon? Here, the task of the researcher is only to become a mediator, a motivator or a facilitator. For example, in preparing for a change in their roles, the researcher formulated what roles they will discuss. The researcher asked them whether they have ever participated in BNPT, the Ministry of Social Affairs, and various NGO workshop activities. The researcher also asked what their role in the activity was. They made mention that they were usually invited as participants. Upon the responses, I proposed to them, what if we change that role? I explained that I don't always be an object, why not be the subject of changes. For example, you can be invited as a speaker because what you experienced is very valuable to be used for learning. But they said, what would we say and how? They explained, if we are told to kill as before it was easier than talking to the crowd, they said while joking. I ensured them, we will prepare how to be a good speaker and what kind of content to be delivered, we will discuss together. The most important thing is to agree upon what our role will be.

Once the role to be played is agreed upon, that is being a speaker at the prevention or in the attempt to break the chain of terrorism, the next agenda to be prepared is to teach them basic public speaking skills and review the content of any material to be delivered in public. In the aspect of public speaking, for example, they are told that an interesting speech could be made when the material content is not memorized. Therefore, they are prepared to avoid inflexible and boring speech. Since the speech should not be memorized, then the researcher encourages them to discuss their personal experiences. Since personal experience is revealed, then, I believe all of you certainly can do it. This is the first step to encourage them to express themselves. The next stage is to discuss what content can be revealed from their personal experiences. The discussion of personal experiences brought them to the material content agreements that cover: First, introducing themselves, names, alias, and what criminal cases they were involved in. Second, it conveys messages regarding their motives for violence. Third, it reveals a bit of what and how the process of violence looks like, and Fourth, it delivers messages for peace.

Since this is a new job for them, so that they are not confused about their required roles, the researcher offers them a type of written example, a kind of presentation paper for each part of their experiences as many as two pages for guidance before they appear later in public. The paper was brought during the presentation to guard in case there are psychological constraints before the audience. After they agreed and were ready to appear as resource speakers, the arena was prepared for them in the form of TALK SHOW activities: Talking with the Peace Warrior Caravan (Former Terrorist Prisoners) with students of senior high schools and university in the district of Poso. The activity was carried out as shown in the picture below: 


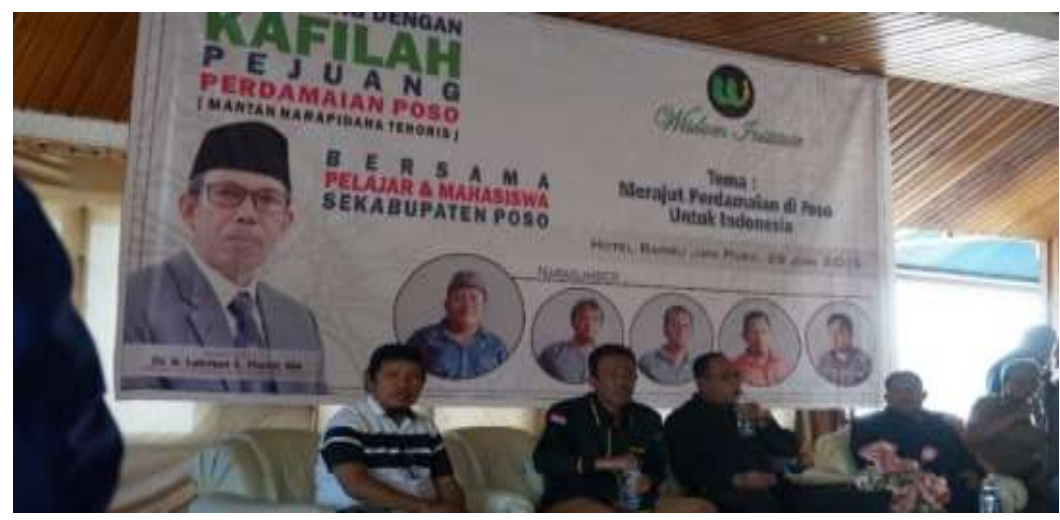

Fig.3. Post-Transformation Ex-Terrorist Activities

The successful event was opened by the Regent of Poso, in this case, represented by the deputy of the district, Samsuri. It was attended by approximately 120 people, students of senior high schools and university students, both Muslim and Christian, religious leaders, Muslim-Christians academicians, NGO stakeholders. The event was guided by the researcher as the host. After the successful event, the next agenda prepared by the researcher is to carry out the same event in Palu with of course taking some kind of evaluation and brainstorming with the Peace Warrior Caravan Team. This is important to acquire pictures regarding constraints or psychological atmosphere they felt when they were at the stage and took roles as resource persons at the event. The efforts like this were made, not only because the next activity was in the provincial capital, but also related to the psychological atmosphere of the participants which would be different. This team was also prepared not only in Palu but also in Jakarta. For the activities held in Palu, it can be seen in Figure 4 below:

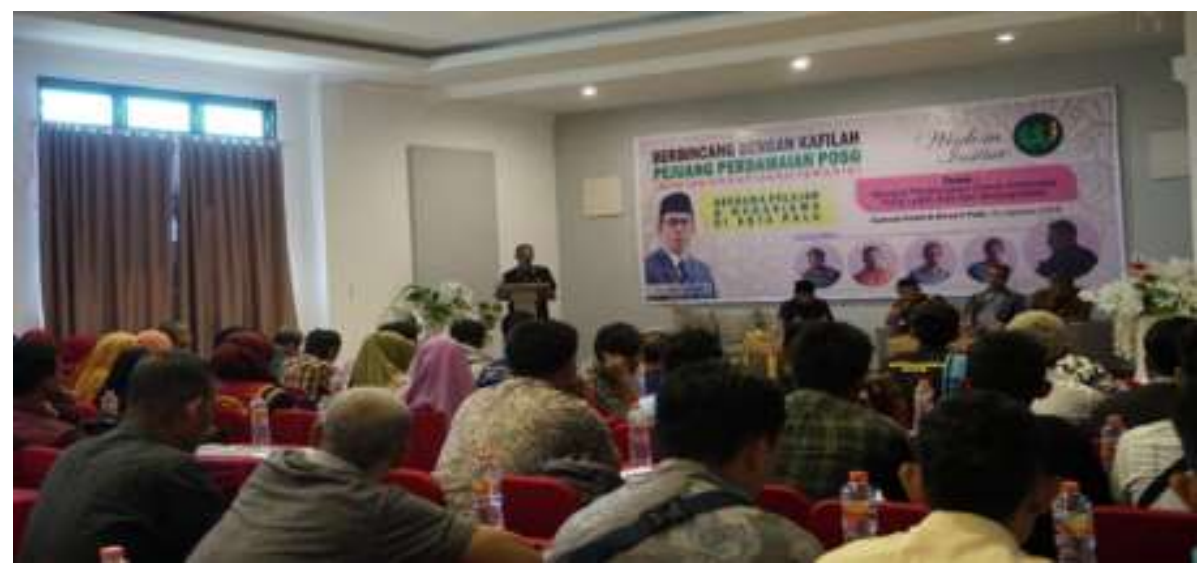

Fig. 4. Self-Actualization of Caravan Peace Fighters in Palu

To give confidence to this group, especially to their leader, the researcher also "binds" the peace record of the team through the signature of Hasanudin that was printed in the 
certificate received by all the participants. In this way, it is expected that there is a psychological burden, in this case, the social responsibility of ustadz Hasan and his group to remain in the line of peacekeepers. For details, see figure 5 of the certificate below:

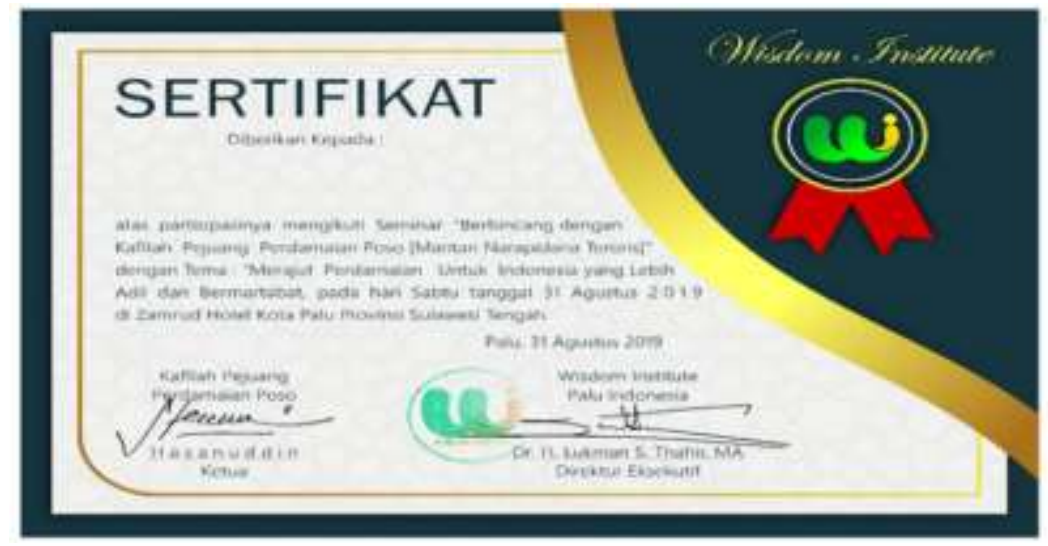

Fig. 5. Certificate of Seminar Participant

That is all the presentation of the results of this study, As a topic for discussion about the efforts to disengagement according to John Horgan or de-radicalization, borrowing the term of BNPT against former terrorist prisoners, I want to start by quoting the views of the Ambassador, Mark D. Wallace, and Frans F. Townsend, in the introduction of Jesse Morton's book (a former terrorist convict, al-Qaeda recruiter in America), and Silber, NYPD intelligent, who helped Morton be released from prison early, due to his cooperation with law enforcement, When Terrorist Come Home: The Need for Rehabilitating and Reintegrating America's Convicted Jihadists. According to Mark Morton and Silber, with their unique personal experiences, they made mention that they found it, difficult forex-terrorist inmates, to leave their ideology or stay away from the environment that triggers their desire to commit acts of violence. In this book, Morton reported about his interviews with terrorist inmates and ex-convicts, who, according to him, some of them remained "cold or ignorant" and still dangerous, while others try to take a new path and struggle with stigmatization, rejection, stressful lives and lack of support [17].

From this information, we can conclude that the process of transforming the identity of the Ex-terrorist was not an easy job. Why not easy? There are at least three reasons; First, to borrow the analysis of Naureen Chowdhury Fink, a program implementer at the International Peace Institute, it was explained that many scholars are more interested in looking at the nature of the spread of terrorist movement, rather than the ways in which the group ends or moves away from violence of their own choices [18]. Second, borrowing the analysis of John Horgan and Kurt Braddock,[19] there is no consensus on what constitutes success in reforming terrorists, let alone what constitutes reform in this context. Third, there is confusion about whether there is a type of rehabilitation in the sense of "de-radicalization" (this term itself which has not been sufficiently conceptualized, let alone defined) as opposed to other interventions to bring about behavioral change. Recent research shows that many of those who stop terrorist activities are not always de-radicalized (mainly intended through changes in thought or belief) and that such de-radicalization is not necessarily a precondition for ensuring their low risk of return to prison again. 
What is offered in this paper, on one hand, does not want to get caught up in the discourse of terrorism that Nauren explained above which is merely pursuing the ways terrorist movement was spread. On the other hand, the study wants to enter further the world of awareness of the ex-terrorist inmates. From here, we will then be able to understand strategies, symbolic forms of interaction of the ex-terrorist inmates, including the spread of terrorism itself. Since the deep and thorough entrance to the world of ex-terrorist awareness, which Mark Morton considered 'not easy', the approach offered does not begin with the BNPT de-radicalization model. Rather, the study employed the disengagement approach offered by John Horgan, by adding several other approaches, especially the author's direct experience with former terrorist convicts. This is what distinguishes the researcher from John Horgan. Both the researcher and John Horgan used the entry point through a psychological door, but the process was different because the author incorporated a phenomenological approach with a highly effective people model of Steven Covey as explained in the results of the study.

Another problem to be emphasized here is the lack of understanding of practitioners of terrorism. This is especially true concerning the identity map of ex-terrorists. Ignoring the exterrorist identity map will obscure the process of releasing or breaking the chain of terrorism amongst the ex-terrorist community. The experience of the researcher in the field, although this does not necessarily guarantee the release of radicalism. Borrowing the language of John Horgan [20], in the process of releasing the chain of terrorism, the first step is to map the attitude and mindset tendencies of each ex-terrorist individual and then sort and select those who are potentially invited to the identity transformation. For the case of ex-terrorist inmates of Poso, for example, based on their mapping, not the researcher's, this could happen because there is truth revealed between them and the researcher. The map of their attitude and mindset tendencies is divided into three parts: First, there is a group of ex-terrorists, when they were out of prison, they only take care of himself and his family's economy. They do not want to mingle not only with the public in general but also with their ex-terrorist colleagues. Secondly, there is another group of ex-terrorists, who do not only think about their families' income, how they can mingle with their community, but also think that Poso will no longer have communal conflicts. Third, there is another group of ex-terrorists who, when they leave prison, still stand by their old ideology of terrorism.

To make the identity transformation workable as intended, based on this mapping, the second group was invited to discuss the intended identity transformation. In this way, many obstacles are encountered, but there are always solutions because we have the same worldview. Through this mapping information as a proposed offer for the research on ex-Poso terrorists, for example, it is interesting to study the typology of the ex-Poso terrorists. For instance, of the 89 ex-Poso terrorists, it is important to better understand who is in these three groups; what the motives are and how their reasons and views are; whether or not they persist in their respective groups.

\section{Conclusions}

Based on the study and descriptions presented above, especially those related to the answers of the research questions, the researcher comes to conclusions as follows: (1) the Poso ex-terrorist convict communities interpret or identify themselves before the identity transformation process to carry out holy missions and therefore they named themselves as the 
Poso Jihadists or Mujahideen. They did not agree if they were called the Poso terrorists. This identity obtained the support from the Muslim community in Poso, and even some religious leaders honored them as heroes, (2) even though this community identified themselves with the Poso Jihadists, in reality, the state punished them with terrorist laws. This is another reality that they encountered, and to solve this problem, they need to transform their identities, from being identified as the Poso jihadists to peacekeepers. The term "peace fighter" is a new identity that they interpret and identify themselves after experiencing the process of identity transformation, and (3) the Poso ex-terrorist inmates' communities interpreted and identified themselves after self-transformation with the new name as the Caravan Warrior of Peace. This new identity was agreed upon by their community by appointing Ustadz Hasanudin as their leaders. This new community showed their role and self-actualization by providing opportunities for them to become key speakers on preventing terrorism, not only in Poso but also in Jakarta. The first two cities have held the events successfully, while the latter is still being prepared for the event.

\section{References}

[1] Samiullah, Ghani Rahman, Shehla Gul, Shakeel Mehmood, "Impacts of Operation Zarb-e-Azb on Spatio-temporal Distribution of Terrorist Incidents in Khyber Pakhtunkhwa", inAbasyn Journal of Social Sciences, Volume 10, Special Issue November 2017, pp. 137

[2] Fact Sheet No. 32, "Human Rights, Terrorism and Counter-terrorism", published by Office of the United Nations High Commissioner for Human Rights, Palais des Nations, 8-14 avenue de la Paix, CH-1211 Geneva 10, Switzerland.

[3] Global Terrorism Index 2017, Measuring and understanding the Impact of Terrorism, (Sydney, New York, and Mexico: Institute for Economic and Peace), p. 15

[4] Report No. 11, Institute for Policy Analysis of Conflict (IPAC), Countering Violent Extremism in Indonesia: Need for a Rethink, 30 June 2014, p. 3

[5] Asia Report, Internasional Crisis Group No. 142, 19 November 2007.

[6] Julie Chernov Hwang, Rizal Pangabean, and Ihsan Ali Fauzi, "The Disengagement of Jihadis in Poso, Indonesia", in Asian Survey, Vol. 53 No. 4, July/August 2013, pp. 755

[7] Shahid N Khan, "Qualitative Research Method - Phenomenology", Asian Social Science; Vol. 10, No. 21; 2014, h. 300-301

[8] J. W. Creswell, Qualitative Inquiry \& Research Design: Choosing Among the Five Approaches, Thousand Oaks, CA: SAGE Publications, Inc., 2013, p. 77

[9] Helen J. Streubert and Dona Rinaldi Carpenter, Qualitative Research in Nursing Advancing the Humanistic Imperative, Fifth Edition, (Wolters Kluwer Health| Lippincott Williams \& Wilkins, 2011), pp. 80-82

[10] Max Weber, translated by Talcott Parson, The Protestant Ethic and The Spirit of Capitalism, (London and New York: Routledge, 1992)

[11] John Horgan, "Individual Disengagement", inLeaving Terrorism Behind Individual and Collective Disengagement, (London and New York: Routledge, 2009), p. 17-27

[12] Lukman S. Thahir, dkk, "Paradigma Baru Penanganan Terorisme di Sulteng", in Jurnal IstiQro', Vol. 13, 2014

[13] Taufik Abdullah (editor), Agama Etos Kerja, dan Perkembangan Ekonomi, (Jakarta: LP3ES, 1979), p. 15

[14] Stephen R. Covey, $7^{\text {th }}$ Habit of Highly Effective People, translator, Budiyanto, 7 Kebiasaan Manusia yang Sangat Efektif, Jakarta: Bina Aksara, 1997

[15] John Horgan, "Individual Disengagement", Dalam Leaving Terrorism Behind Individual and Collective Disengagement, (London and New York: Routledge, 2009

[16] Helen J. Streaubert dan Dona Rinaldi Carpenter, Qualitative Research in Nursing Advancing the Humanistic Imperative, Fifth Edition, (Wolters Kluwer Health | Lippincott Williams \& Wilkins: A Macmillan Company, 2011), pp. 81-82 
[17] Jesse Morton dan Mitchell D. Silber, When Terrorism Come Home: The Need for Rehabilitating and Reintegrating America's Convicted Jihadists, Dalam https:-//www.counterextremism.com/sites/default/files/CEP\%20Report_When\%20Terrorists\%20Come\%20 Home_120618, p. 2

[18] Naureen Chowdhury Fink dan Ellie B. Hearne, "Beyond Terrorism: Deradicalization and Disengagement from Violent Extremism", inhttps://www.ipinst.org/wpcontent/uploads/publications/beter.pdf

[19] John Horgan dan Kurt Braddock, "Rehabilitating the Terrorists?: Challenges in Assessing the Effectiveness of De-radicalization Programs", in Terrorism and Political Violence, ( Routledge, Taylor and Francis Group, 2010), pp. 268.

[20] John Horgan, "Deradicalization or Disengagement? A Process in Need of Clarity and a Counterterrorism Initiative in Need of Evaluation", in perspectives on Terrorism, Vo. 2. No. 4. 2008 